\title{
Brand Heritage, Corporate Reputation and Brand Image on Buying Intention
}

\author{
Guntur Pradipto Aji Raharjo ${ }^{1}$
}

1Program Studi Magister Manajemen Universitas Kristen Maranatha, Bandung, Indonesia

\begin{tabular}{|c|c|}
\hline ARTICLE INFO & ABSTRACT \\
\hline Received June 2020 & This study aims to prove empirically how these three factors can \\
\hline Accepted June 2020 & influence purchasing decisions. This research model involves \\
\hline Published July 2020 & $\begin{array}{l}\text { several variables of brand heritage, corporate reputation, } \\
\text { purchase intention and brand image as additional variables. This }\end{array}$ \\
\hline $\begin{array}{l}\text { Keywords: Brand heritage, } \\
\text { Corporate reputation, Brand } \\
\text { image, Buying intention }\end{array}$ & $\begin{array}{l}\text { research proves that brand heritage is still an important driver of } \\
\text { customer purchase intentions or intentions. Similar results also } \\
\text { occur in corporate reputation that supports this view that } \\
\text { corporate reputation has a positive influence on buying } \\
\text { intentions for Datsun products, and brand image that also } \\
\text { influences consumers to buy Datsun products. }\end{array}$ \\
\hline
\end{tabular}

\section{Introduction}

Datsun is a four-wheeled vehicle brand that was present in Indonesia around the 1950-60s. But the name Datsun was frozen and later replaced with the name 'Nissan' with the aim of making the company more globally developed. After 30 years of being frozen, in 2012 Nissan Motor Co., announced the return of the Datsun brand. In Indonesia. PT Nissan Motor Indonesia announced this in September 2013. Certainly the presence of this Datsun is already familiar to some Indonesian people who have known and even owned a Datsun car, because Datsun has a great history in the Indonesian automotive industry. Even among those who argue that Datsun is a brand that has heritage values.

Several studies have been conducted to identify Brand heritage. Some researcher [1] said that heritage brands are not just a matter of time or a moment a brand can survive in the market, heritage brands have a more specific understanding, where a brand can be said as a heritage brand because of the existence of the brand in the midst of consumers who can survive well. The size of a brand's existence is not only based on a fact that records that the brand has existed from ancient times until now, but also how the brand has relevance to the existing market both the existing market in the past until now and how the brand has appeal for loyal customers to potential customers for the brand. Brand reputation ranks second out of 10 reasons why people buy a vehicle, corporate reputation is also one of the 6 reasons why people will choose a car brand that they will use.

Corporate reputation is formed on the basis of ongoing interaction with stakeholders from time to time, the initial actions of a company and the history and heritage of the product brand. Brand heritage can help to generate a willingness to accept high prices and form customer loyalty, but perceptions of the company's reputation are 
still needed in the context of forming a new brand image and also consumer buying interest. Not a few previous studies have examined the effect of brand image on purchasing decisions. However, not much research has examined the relationship between purchasing decisions made by the public (consumers) with the development of brand image, especially in luxury products.

\section{Research Methods}

This research model involves several variables of brand heritage, corporate reputation, purchase intention and brand image as additional variables. This research proves that brand heritage is still an important driver of customer purchase intentions or intentions.

\section{Result and Discussion}

Brand heritage is identified with a past picture of a product that has a history. The study of [2] revealed that brand heritage as a dimension of identity that can be found in the track record, long life, core values, use of symbols, especially in the dimensions of their organization myakini that its history is important. Furthermore, [1] explained that Heritage Brands represent longevity and sustainability, as proof that the core values and performance of the products provided are reliable. In their research, they believe that to explore the perceived values and results of brand heritage, they present the methodology and results of empirical studies using the least squares partial path modeling approach. The results of his research show the significant effect of brand inheritance on consumer attitudes and behavior related to a given brand. Other studies [3] reveal that competition today is a competition that refers to identity and reputation. Because the company's reputation is based on ongoing interaction with stakeholders from time to time, the company's initial actions and history and inheritance are very important. By referring to consumers who have inherited meaning, a brand's inheritance can result in increased brand loyalty and a willingness to accept higher prices. However, better knowledge of the conditions and drivers of brand heritage, and the effects of brand heritage on company reputation and stakeholder perception behavior, are still needed. The main research objective of this paper is to examine the important role of brand heritage as an important driver of a company's reputation and perception of customer value, as well as its influence on brand image and customer purchase intention.

Corporate reputation: the company's reputation is formed on the basis of ongoing interaction with stakeholders from time to time, the initial actions of a company and the history and heritage of the product brand [3]. In his further research it was also revealed that a positive corporate reputation can be seen as an important element in creating a brand image, understood as the amount of actual experience and / or perception through interaction with the company from time to time. In other words, reputation based on past corporate actions is an important element of brand image in the present with the prospect of satisfying consumer experience in the future. Furthermore, [4] revealed that the company's negative reputation significantly worsened consumers' attitudes and buying intentions. However, this type of reputation is not a determining factor for consumer cognitive processes. The results imply that marketing 
managers need to manage negative reputations carefully because negative company reputations exacerbate consumer cognitive processes. However, consumers are not influenced by certain types of negative information, so companies can reduce the negative impact of their negative reputation with other types of positive reputation. The same thing was also expressed by [5] that organizations with better reputations outperform their rivals, there is uncertainty about how to create such a reputation, especially among managers who are responsible for this task.

This confirms that a good reputation is very important for companies to instill customer trust. Meanwhile [6], [7] confirmed in his research that a good company reputation will have an impact on customer loyalty. This is similar to what was expressed [8] that the totality of customers in addition to marketing mix efforts, is also greatly influenced by the reputation of the company itself.

Brand Image: Basically brands often have historical value, where history is a picture of the past of a brand. The value of this history can keep a brand standing for decades, even centuries. From this was born a legacy of "heritage". The heritage aspect of a brand itself shows longevity and sustainability as a promise to stakeholders that the brand's core values and performance are authentic and true. Research conducted [9] found that brand image affects consumer satisfaction and then repurchases. This is in line with what has been found by [10] that brands influence the purchasing decisions. Furthermore, [11] revealed that products that have a good brand will drive purchase intentions by consumers. Products that have a good brand reputation will be more trusted by consumers compared to ordinary brands. Brand perception expressed [12] confirms that brand perception influences consumer purchase intentions. In his research it was also revealed that the price of a product from the brand contributed to the purchase decision.

Buying Intention: Some buying intention factors expressed by [13] are a complexity of marketing activities. The power of marketing also encourages consumers to have purchase intentions. Research conducted by [14] confirms the power of word of mouth marketing to encourage consumer intentions. But this is also not free from the influence of the brand. Research conducted by [15] reveals that consumer purchase intentions are influenced by expensive brands. The advantages of this expensive brand have higher trust than ordinary brand names. This was reaffirmed by [16], [17] that a brand that had a good reputation would have a stronger influence on purchase intentions compared to ordinary brands. A similar opinion was expressed by [18], [19] who asserted that consumers would make purchases of brands that have a good reputation. In addition to a good reputation, product quality and brand price perception also gives impetus to consumers' intention to make a purchase. In addition to brands that have won the trust, the power of social media is very influential on purchase intentions. Research conducted [20], [21] revealed that social media is very helpful for marketing in encouraging consumer purchase intentions. The same thing was also expressed by [22], [23] which emphasized that in addition to social media, purchase intention was also influenced by the brand and country of origin of the brand. This shows that brand reputation and the strength of social media greatly affect consumers' intention to make a purchase. 


\section{Conclusion}

Corporate reputation in this case also affects consumers to buy products. So it is time for the company to maintain the company's reputation so it does not go down or become bad so consumers are not interested in buying their products. To maintain a brand's reputation, a company must be concerned with performance and innovation for its products. The company's brand heritage is used as a benchmarking to improve the quality of its products. So that the history of a brand that has been built for a long time does not become useless even, if necessary, it has to be an attraction. If the purchasing decision is in the hands of consumers, the company must really have good marketing principles.

This is related to creating value to consumers, that value can be in the form of price and discount policies (economic value), can be in the form of functions, features, and quality (functional value), and can be in the form of affective value, and of course social value. Product quality must also be a particular concern of the company because product quality is closely related to the company's reputation. Companies that have a good reputation will be perceived by consumers as having high quality products. This is closely related to the brand image that is built with innovations that can drive the intention of consumers to make purchases.

The results of the review can be considered as a study, especially focusing on product innovation from brands that are considered to have a heritage then associated with brand image and corporate reputation. In addition, qualitative research can be done with the subject of the company along with the phenomena that occur in the brand. Qualitative approaches to brand heritage, corporate reputation, brand image and buying intention in brands will focus more on the factors that influence purchasing intentions.

\section{References}

[1] K. P. Wiedmann, N. Hennigs, S. Schmidt, and T. Wuestefeld, "Drivers and outcomes of brand heritage: Consumers' perception of heritage brands in the automotive industry," J. Mark. Theory Pract., vol. 19, no. 2, pp. 205-220, Apr. 2011, doi: 10.2753/MTP1069-6679190206.

[2] J. M. T. Balmer and S. A. Greyser, "Corporate Brands with a Heritage - Bradford University School of Management Working Paper," Bradford, 2007.

[3] K. P. Wiedmann, N. Hennigs, S. Schmidt, and T. Wuestefeld, "Brand heritage and its impact on corporate reputation: Corporate roots as a vision for the future," Corp. Reput. Rev., vol. 16, no. 3, pp. 187-205, Sep. 2013, doi: 10.1057/crr.2013.10.

[4] N. Y. Jung and Y. K. Seock, "The impact of corporate reputation on brand attitude and purchase intention," Fash. Text., vol. 3, no. 1, 2016, doi: 10.1186/s40691-0160072-y.

[5] V. Pires and G. Trez, "Corporate reputation," Rev. Gestão, vol. 25, no. 1, pp. 47-64, 2018, doi: 10.1108/rege-11-2017-005.

[6] S. M. C. Loureiro, E. M. Sarmento, and G. Le Bellego, "The effect of corporate brand reputation on brand attachment and brand loyalty: Automobile sector," Cogent Bus. Manag., vol. 4, no. 1, 2017, doi: 10.1080/23311975.2017.1360031. 
[7] A. Vahabzadeh, H. Vatanpour, R. Dinarvand, A. Rajabzadeh, J. Salamzadeh, and M. Mohammadzadeh, "Impact of corporate reputation on brand differentiation an empirical study from Iranian pharmaceutical companies," Iran. J. Pharm. Res., vol. 16, no. 4, pp. 1658-1670, 2017, doi: 10.22037/ijpr.2017.2128.

[8] R. Santoso, R. Shinta, and A. Y. A. Fianto, "Composing Marketing Mix for Better Destination Brand in Jawa Timur, Indonesia," Maj. Ekon., vol. XXIV, no. 1411, pp. 158-167, 2019.

[9] B. Ranjbarian, A. Sanayei, M. R. Kaboli, and A. Hadadian, "An Analysis of Brand Image, Perceived Quality, Customer Satisfaction and Re-purchase Intention in Iranian Department Stores," Int. J. Bus. Manag., vol. 7, no. 6, Mar. 2012, doi: 10.5539/ijbm.v7n6p40.

[10] H. H. Chovanová, A. I. Korshunov, and D. Babčanová, "Impact of Brand on Consumer Behavior,"Procedia Econ. Financ., vol. 34, no. 15, pp. 615-621, 2015, doi: 10.1016/s2212-5671(15)01676-7.

[11] T. Djatmiko and R. Pradana, "Brand Image and Product Price; Its Impact for Samsung Smartphone Purchasing Decision," Procedia - Soc. Behav. Sci., vol. 219, pp. 221-227, 2016, doi: 10.1016/j.sbspro.2016.05.009.

[12] T. S. Erdil, "Effects of Customer Brand Perceptions on Store Image and Purchase Intention: An Application in Apparel Clothing," Procedia - Soc. Behav. Sci., vol. 207, pp. 196-205, 2015, doi: 10.1016/j.sbspro.2015.10.088.

[13] R. Santoso, R. Shinta, and A. Y. A. Fianto, "Pengaruh Bauran Pemasaran Jasa terhadap Keputusan Berkunjung ke Wisata Bahari Jawa Timur," Manaj. dan Bisnis, vol. 4, pp. 1-14, 2019.

[14] M. R. Jalilvand and N. Samiei, "The Effect of electronic Word of Mouth on Brand Image and Purchase Intention: An Empirical Study in The Automobile Industry in Iran," Mark. Intell. Plan., vol. 30, no. 4, pp. 460-476, Jun. 2012, doi: 10.1108/02634501211231946.

[15] Q. Bian and S. Forsythe, "Purchase intention for luxury brands: A cross cultural comparison," J. Bus. Res., vol. 65, no. 10, pp. 1443-1451, Oct. 2012, doi: 10.1016/j.jbusres.2011.10.010.

[16] A. Mongi, Lidya; Mananeke, Lisbeth; Repi, "Kualitas Produk, Strategi Promosi dan Harga Pengaruhnya Terhadap Keputusan Pembelian Kartu Simpati Telkomsel di Kota Manado," J. EMBA, vol. 1, no. 4, pp. 2336-2346, 2013, doi: 10.1055/s-0032-1328522.

[17] F. Musay, "Pengaruh Brand Image Terhadap Keputusan Pembelian (Survei Pada Konsumen Kfc Kawi Malang)," J. Adm. Bisnis S1 Univ. Brawijaya, vol. 3, no. 2, pp. $1-7,2013$.

[18] P. Sari, Hutami Permita; Rahmawati, "Pengaruh Citra Merek, Fitur, dan Persepsi Harga Terhadap Keputusan Pembelian (Studi Pada Konsumen Smartphone Xiaomi di DIY)," J. Manaj. Bisnis Indones., vol. 5, no. 3, pp. 222-237, 2016, doi: 10.1007/s00106-016-0261-4.

[19] Vivil Yazia, “Pengaruh Kualitas Produk, Harga dan Iklan Terhadap Keputusan Pembelian Handphone Blackberry (Studi Kasus Blackberry Center Veteran Padang)," Economica, vol. 2, no. 2, pp. 165-173, 2014. 
[20] R. R. Adetunji, M. R. Sabrina, and I. M. Sobhi, "User-Generated Contents in Facebook, Functional and Hedonic Brand Image and Purchase Intention," SHS Web Conf., vol. 33, p. 00084, 2017, doi: 10.1051/shsconf/20173300084.

[21] R. Imtiaz, S. Q. Ul Ain Kazmi, M. Amjad, and A. Aziz, "The impact of social network marketing on consumer purchase intention in pakistan: A study on female apparel," Manag. Sci. Lett., vol. 9, no. 7, pp. 1093-1104, 2019, doi: 10.5267/j.msl.2019.3.015.

[22] C. Nam, H. Dong, and Y. A. Lee, "Factors influencing consumers' purchase intention of green sportswear," Fash. Text., vol. 4, no. 1, 2017, doi: 10.1186/s40691017-0091-3.

[23] E. Setiadi, M. Adiwijaya, and H. Subagio, "The Impact of Brand Awareness and Country of Origin on Purchase Intention with Mediation of Self Congruity on Chinese Brand Automotive Products Wuling," Petra Int. J. Bus. Stud., vol. 1, no. 2, pp. 70-79, 2018, doi: 10.9744/ijbs.1.2.70-79. 